\title{
Soya Bitkisinde Tepe Sürgün Budamasının Biyomas Verimine Etkisi
}

\author{
Metin DAĞTEKİN ${ }^{2}$, M. Emin BİLGİL̇ं 2 \\ ${ }^{1}$ Çukurova Üniv. Ceyhan Meslek Yüksekokulu Ceyhan-ADANA, ${ }^{2}$ Doğu Akdeniz Tarımsal Araştırma Enstitüsü ADANA \\ ${ }^{1}$ https://orcid.org/0000-0002-4191-0540, ${ }^{2}$ https://orcid.org/0000-0003-3820-8387 \\ $\bowtie$ : mmdagtekin@gmail.com
}

\begin{abstract}
ÖZET
Bu çalışmanın amacı, soya bitkisinde tepe sürgününün kesilerek bitki mimarisinde oluşturulacak değişimin biyomas verimini artırma potansiyelini belirlemektir. Araştırmada Çukurova Bölgesinde ana ürün olarak yaygın üretimi yapılan Arısoy ve Lider soya çeşitleri materyal olarak kullanılmıştır. Tepe sürgün budama uygulamaları bitkiler üç yapraklı (3B) ve beş yapraklı (5B) aşamada iken gerçekleştirilmiştir. Araştırmada Arısoy çeşidinde dekara tohum verimi kontrol grubunda $461 \mathrm{~kg}$, 3B uygulamasinda $440 \mathrm{~kg}$, 5B uygulamasında $553 \mathrm{~kg}$ olarak gerçekleşmiştir. Bu değer Lider çeşidinde ise sırası ile 540,478 ve $519 \mathrm{~kg}$ olarak gerçekleşmiştir. Araştırma sonucunda, tohum verimi en yüksek Arısoy çeşidinin 5B uygulamassında görünürken, Lider çeşidi ise iki farklı uygulamaya (3B ve $5 \mathrm{~B})$ negatif tepki vermiştir. $\mathrm{Bu}$ durum, bölgemizde Arısoy çeşidinde 5B döneminde yüksek tohum ve biyomas verimi için uygun bitki mimarisini geliştirecek budama mekanizasyonun uygulanabilir olduğunu ortaya çıarmıştır.
\end{abstract}

\section{The Effect of Top Shoot Pruning on the Biomas Yield in Soybean Plant}

\section{ABSTRACT}

The aim of this study was to determine the potential biomass yield increase by the change created in plant architecture by cutting the top shoot of soybean. In the research, Arisoy and Lider soybean varieties, which are widely cultivated in Çukurova Region, were used as materials. In the research, plants top shoots were pruned during three-leaf (3B) and five-leaf (5B) stages. In the study, the seed yield per decare in the Arisoy variety was $461 \mathrm{~kg}$ in the control group, 440 $\mathrm{kg}$ in $3 \mathrm{~B}$ application and $553 \mathrm{~kg}$ in $5 \mathrm{~B}$ application. These values were realized as 540, 478 and $519 \mathrm{~kg}$ in the Leader variety, respectively. As a result of the research, while the seed yield was highest in the $5 \mathrm{~B}$ application of the Arisoy variety, the Leader variety responded negatively to two different applications (3B and 5B). This situation revealed that pruning mechanization, which will develop suitable plant architecture for high seed and biomass yield in 5B period in Arısoy variety in our region, is applicable.
Araştırma Makalesi

\section{Makale Tarihçesi}

Geliş Tarihi : 22.02 .2020

Kabul Tarihi : 30.04 .2020

\section{Anahtar Kelimeler}

Budama

Biyomas verimi

Soya

Tepe sürgünü

To Cite : Dağtekin M, Bilgili M.E 2020. Soya Bitkisinde Tepe Sürgün Budamasının Biyomas Verimine Etkisi, The Effect of Top Shoot Pruning on the Biomas Yield in Soybean Plant. KSÜ Tarım ve Doğa Derg 23 (5): 1192-1199. DOI: 10.18016/ksutarimdoga.vi.692943.

\section{GİṘŞ}

Küresel nüfus artışının gıda talebini karşılamanın esas yolu tarımsal verim artışlarından geçmektedir. Yüzyılın mucize bitkisi olarak nitelendirilen soya [Glycine max (L)], insan gidası, hayvan yemi, endüstride ham madde olarak kullanımı ve toprağa kazandırdığı azot ile Dünyada ekonomik olarak üretilen en önemli yağ ve protein bitkilerinden biridir. Soya, dünyada \%58'lik payla en fazla üretimi yapılan yağlı tohumlu bitkidir (Faostat, 2018). Türkiye, soya

\section{Research Article}

Article History
Received $\quad: 22.02 .2020$
Accepted $\quad: 30.04 .2020$

Keywords

Pruning

Biomass yield

Soybean

Top shoot ihtiyacının önemli bölümünü ithal etmektedir. Türkiye'de soya üretimi daha çok güney illerinde yoğunlaşmıştır. 2017 yılında 351.317 ton ile Türkiye soya üretiminin $\% 58,3$ ü Adana ilinde yapılmış olup, bu oran 2018 yılında \%2 oranında artmıştır. Genel olarak Adana, Mersin, Osmaniye, Kahramanmaraş ve Samsun illerinin soya üretimi toplam soya üretiminin yaklaşık \%96'sını karşılamaktadır (TÜİK, 2018).

Soyada bitki başına dal sayısı, ana verim bileşeni olan birim alana tohum sayısını etkileyen önemli bir 
parametredir. Ana sapın dominant olduğu normal bitki mimarisinde yan dallar zaylf kalmaktadır. Soyada erken dönemde oksin üreten tepe sürgününün alınması, tepe sürgününün baskınlığını kaldırıp bol ve güçlü yan dal üretimiyle sonuçlanmaktadır. Bu durum birim alanda toplam çiçek, fertil çiçek, bakla ve tohum sayısını artırmaktadır (Robinson ve ark., 2013). Bu durum büyüme düzenleyicilerle gerçekleştirilebilse de ciddi verim düşüşleri riski oluşturmaktadır. Soya bitkisinde verim düşmesinde etkili olan etmenler konusunda yapılan çalışmalardan bazıları aşağıda sunulmuştur;

Soya çiçeklerinin büyük bir kısmını gelişim esnasında silkmektedir (Kokubun, 2011). Islam ve ark., (2010), soyada çiçeklerin \%70-85'ini silktiğini bildirmiştir. Soyada önemli sayıda çiçek ve bakla doğal olarak silkmekte ve verim üzerinde önemli oranda olumsuz etki yapmaktadır (Nanokowa ve ark., 2007). Bu kayıpları azaltmak bu türün verimini artırmada önemli bir çözümdür (Kokubun ve Honda, 2000). Meyve ve tohum silkme birçok diğer türde de verim potansiyellerini yükseltmede ana kisitlayıcı faktörlerden biridir (Ruan ve ark., 2012). Günümüzde reprodüktif organların silkme mekanizması hala iyi anlaşılmış değildir (Dybing ve Reese, 2008). Çiçek silkmesi çevresel stres koşullarında artmakta fakat aşırı stresin olmadığı koşullarda da çokça gerçekleşmektedir. Soyada sapa yakın çiçeklerin sadece \%17'si silkerken sapın daha uzağında yer alanların \%75'i silkmektedir (Brun ve Betts, 1984).

Yapılan çalışmalar ana sap veriminin farklı çevresel koşullar altında çoğunlukla stabil olduğunu ve dane verimin çoğunlukla yan dalların verimiyle korelasyon halinde olduğunu göstermektedir ( Frederick ve ark., 2001; Norsworhy ve Shipe, 2005). Stres nedeniyle reprodüktif dönemde soyada görülen verim düşüşlerinin ana sebebi bitki başına düşen dal veriminin azalmasıdır ( Frederick ve ark., 2001; Linkemer ve ark., 1998). Soya tipik olarak apikal dominansi sergiler ki bu durumda yan dallarm büyümesi ana sap tarafindan baskılanır. Ana sap ucu alındığında yan dallar baskıdan kurtulur ve yan dal verimi artar (Ali ve Fletcher, 1970).

$\mathrm{Bu}$ çalışmanın amacı, Çukurova bölgesinde ana ürün olarak yetiştirilen iki farklı soya çeşidinde tepe sürgününün kesilerek bitki mimarisinde oluşturulacak değişimin biyomas verimini artırma potansiyelini belirlemektir. Dallanmanın artırılması sadece verimi değil aynı zamanda biyomas üretimini de arttıracağından protein bitkisi olan soyanın silaj amaçlı yetiştirilmesinde önemli faydalar sağlayacaktır.

\section{MATERYAL ve METOD}

\section{Materyal}

Araştırmada Çukurova bölgesinde ana ürün olarak yaygın üretimi yapılan Arısoy ve Lider soya çeşitleri materyal olarak kullanılmıştır. Araştırmada kullanılan tohumların bazı teknik özellikleri Çizelge 1 'de verilmiştir.

Çizelge 1. Soya tohum çeşitlerinin teknik özellikleri

Table 1. Technical characteristics of soy seed varieties

\begin{tabular}{lll}
\hline Özellikler (Features) & Arısoy & Lider \\
\hline $\begin{array}{l}\text { Olum Grubu } \\
\text { (Formation group) }\end{array}$ & 3.6 & 3.8 \\
\hline $\begin{array}{l}\text { Bitki Boyu (cm) } \\
(\text { Plant height }(\mathrm{cm}))\end{array}$ & $95-120$ & $115-120$ \\
\hline $\begin{array}{l}\text { Ilk Bakla Yüksekliği (cm) } \\
\text { (First Pods Height (\%)) }\end{array}$ & 15 & $12-14$ \\
\hline $\begin{array}{l}\text { 100 Tohum Ağırlığ }(\mathrm{g}) \\
(100 \text { seed weight }(\mathrm{g}))\end{array}$ & $14-16$ & - \\
\hline $\begin{array}{l}\text { Tohum Protein Oranı (\%) } \\
\text { (Seed protein ratio (\%)) }\end{array}$ & $28-39$ & $34-36$ \\
$\begin{array}{l}\text { Tohum Yağ Oranı (\%) } \\
(\text { Seed oil rate (\%)) }\end{array}$ & $19-23$ & $21-22$ \\
\hline
\end{tabular}

Araştırma, Adana İli Yüreğir İlçesi’nde bulanan Doğu Akdeniz Tarımsal Araştırma Enstitüsü Müdürlüğü deneme arazilerinde yürütülmüştür. Deneme alanı koordinatları " $36^{\circ} 51^{\prime} 18^{\prime}$ " Kuzey enlemi ve $35^{\circ} 20^{\prime} 51^{\prime}$ Doğu boylamında" olup, rakımı 12 m'dir. Araştırma alanın koordinatları ve uydu görüntüsü Şekil 1'de verilmiştir. Araştırmanın yürütüldüğü parsellere ait toprak bünye özellikleri: \% 18-20 kum, \% 29-35 kil, \% 40-50 arasında silt (Bünye, killi-tın); \% 15-26 kireç; \% 0.8- 1.9 organik madde; \% 0.02-0.15 tuzluluk; $\mathrm{pH} 7.9$; Azot 2-5 kg da-1; Fosfor 3-16 kg da-1; Zn 0.2-0.5 ppm arasındadır.

\section{Uygulanan Kültürel - Bakım İşlemleri}

Soya çeşitlerin budamasında akülü çit kesme makinası kullanılmıştır (Şekil 2). Soya çeşitlerinin yetiştirilmesinde uygulanan kültürel ve bakım işlemleri Çizelge $2^{‘}$ de verilmiştir.

\section{Yöntem}

\section{Deneme Yöntemi ve Uygulama Tekniği}

Soya bitkisinde, erken iki farklı dönemde tepe sürgün budamasının ürün verimine etkisini belirlemek amacıyla yapılan bu çalışmada, dallanmanın artırılması sadece verimi yükseltmekle kalmayıp biyomas üretimini de artırabilecektir. Araştırmada uç budaması elle yapılmıştır. Denemeler bünyesinde oluşturulmuş ek alanlarda, el tipi akülü farklı özellikteki bahçe/çit biçme makinası ile uç budama uygulamaları yapılmıştır.

Araştırma, tesadüf bloklarında bölünmüş parseller deneme deseninde, dört tekerrürlü olarak kurulmuştur. Üç farklı uygulama gerçekleştirilmiştir. Bunlar;

- Kontrol (0B uygulamasi) 
- Bitkiler üç adet üçyaprakçıklı (trifoliate) yaprak oluşturduğunda uç alma (3B uygulaması)

- Bitkiler beş adet üçyaprakçıklı (trifoliate) yaprak oluşturduğunda uç alma (5B uygulaması)

Parseller arasında en az $1.5 \mathrm{~m}$, tekerrürler arasında 2 $\mathrm{m}$ boşluk bırakılmıştır. Hasatta kenarlardaki birer sıra ve parsel başlarında ise $0.5 \mathrm{~m}$ kenar tesiri olarak atılmıştır. Her parsel 4 sıradan oluşmaktadır. Her parselin uzunluğu $5 \mathrm{~m}$ ve genişliği $2.8 \mathrm{~m}$ olup, alanı 14 $\mathrm{m}^{2}$ olmuştur.

\section{İncelenen Özellikler ve İnceleme Yöntemleri}

Dal sayısı (adet bitki-1): Hasat edilen orta iki sıradaki bitkilerinin dallarının tamamı sayılarak hasat edilen bitki sayısına bölünerek hesaplanmıştır.
Biyomas ağırlığı (g): Olgunlaşma döneminde, her parselden tesadüfi olarak seçilen $1 \mathrm{~m}^{2}$ alanda bulunan bitkiler toprak yüzeyinden biçildikten sonra firında 80 ${ }^{\circ} C^{\prime}$ de 72 saat kurutularak tartılmıştır.

Hasat indeksi (\%): Tohum veriminin biyomas ağırlığına oranlanmasıyla hesaplanmıştır.

Tohum verimi (kg da-1): Biyoması hesaplamak üzere hasat edilmiş ve güneşte kurutularak tartılmış biyomasın parsel harman makinasından geçirilerek daneler ayrılmış, tartılmış ve parsel veriminden gidilerek dekara tohum verimi hesaplanmıştır.

Hasat artığı miktarı ( $\mathrm{kg}$ da-1): Kurutulmuş ve tartılmış toplam biyomasın parsel harman makinasından geçirilip tohumları alındıktan sonra tartılmasıyla hesaplanmıştır.

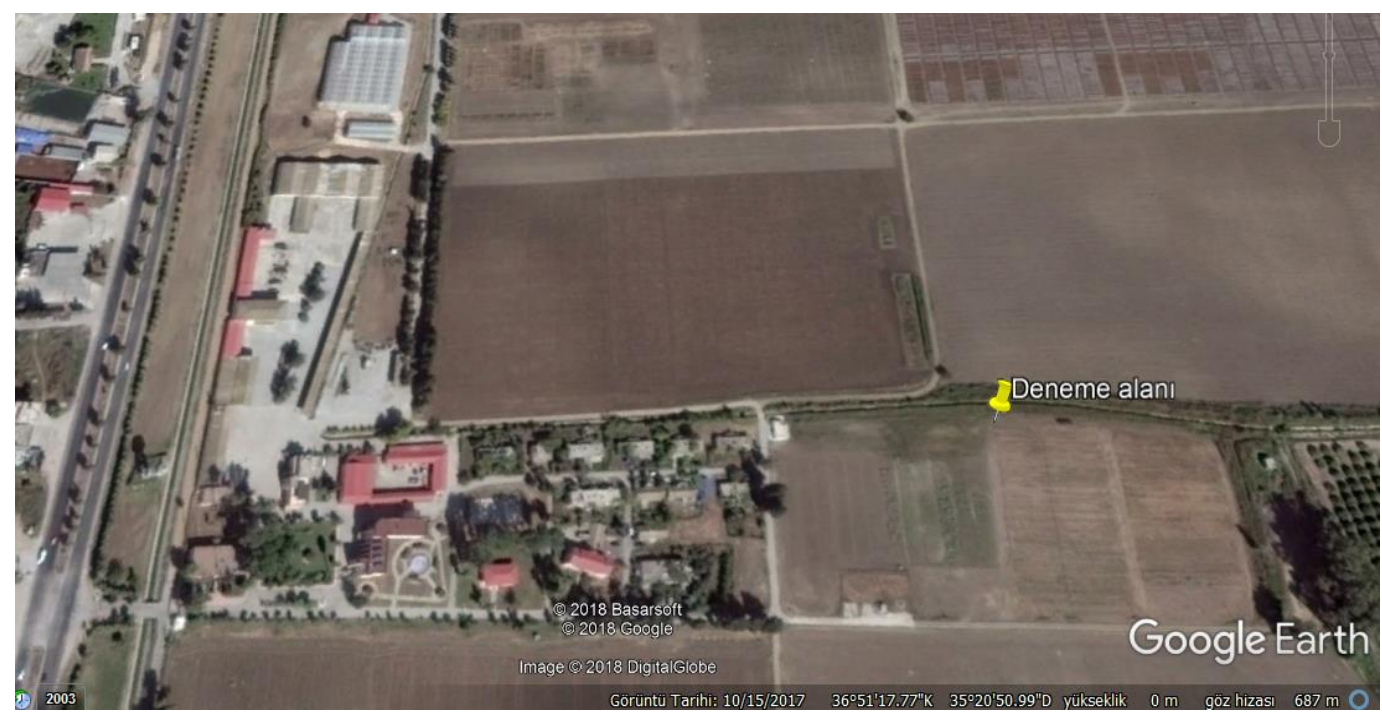

Şekil 1. Araştırma alanın koordinatları ve uydu görüntüsü Figure1. Coordinates and satellite view of the research area

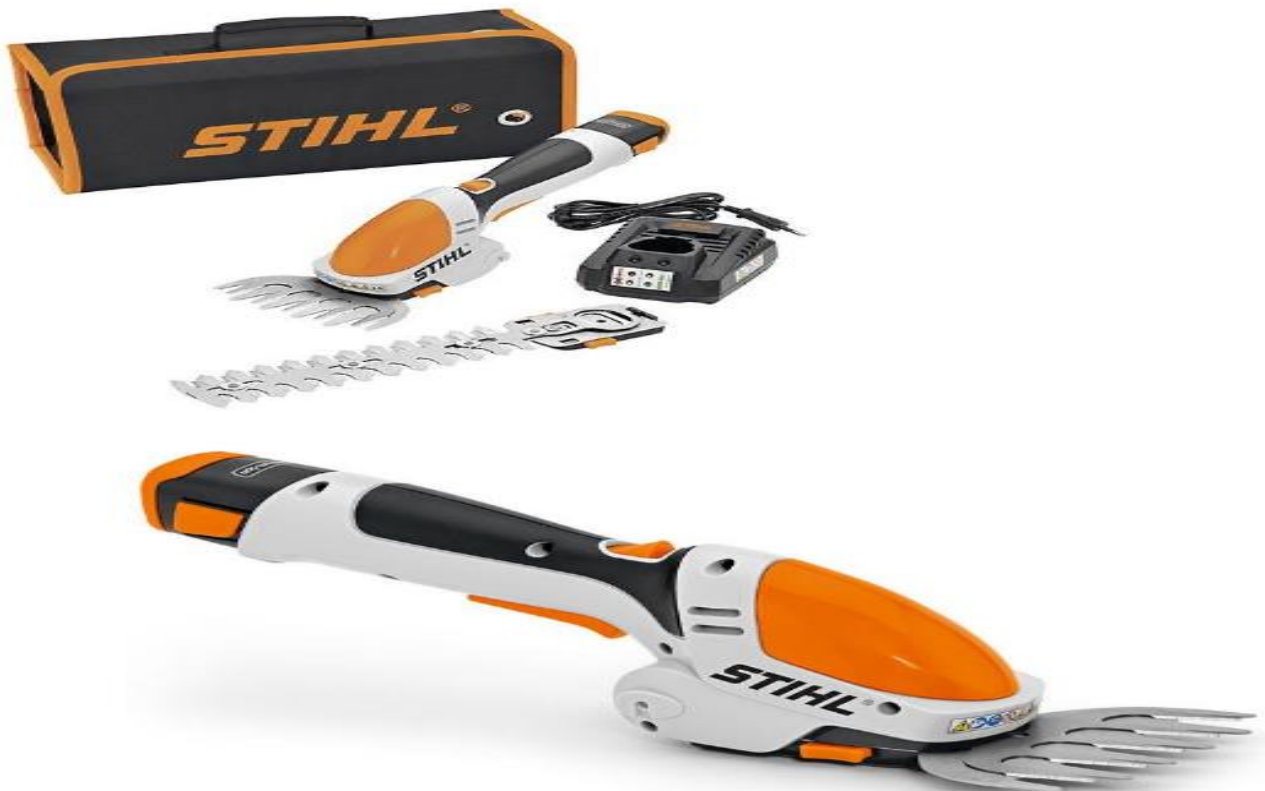

Şekil 2. El tipi akülü çit biçme makinası

Figure 2. Hand-held cordless mower 
Çizelge 2. Soya Çeşitlerin Yetiştirilmesinde Uygulanan Kültürel-Bakım İşlemleri

Table 2. Cultural-Care Processes Used in Growing Soy Varieties

\section{Uygulama ve Bakım işlemleri (Application and cultivation processes)}

\begin{tabular}{|c|c|}
\hline $\begin{array}{l}\text { Toprak İşleme } \\
\text { Soil Tillage }\end{array}$ & $\begin{array}{l}\text { Sonbaharda tarla çizel+gobledisk ile sürülerek ekim öncesi ön hazırlık yapıldı. } \\
\text { Ekimden önce kültivatörle yüzeysel olarak tekrar toprak kabartıldı ve sırt listeri + } \\
\text { sırt tapanı uygulanarak tohum yatağı hazırlığı işlemleri tamamlanmıştır. }\end{array}$ \\
\hline $\begin{array}{l}\text { Ekim } \\
\text { Sowing }\end{array}$ & $\begin{array}{l}\text { Ekim } 30 \text { Nisan'da yapılmıştır. Ekim işleminde dört ekici ayağa sahip pnömatik ekim } \\
\text { makinası kullanılmıştır. Tohumlar } 70 \mathrm{~cm} \text { sıra arası ve } 4 \mathrm{~cm} \text { sıra üzerine }(4-6 \mathrm{~cm} \\
\text { derinliğe) düşecek şekilde ekilmiştir. }\end{array}$ \\
\hline $\begin{array}{l}\text { Gübreleme } \\
\text { Fertilization }\end{array}$ & $\begin{array}{l}\text { Ekimle birlikte pnömatik ekim makinası ve bitki gelişim döneminde siraya gübre } \\
\text { dağttma makinası ile dekara } 30 \mathrm{~kg} \text { Monoamonyum Fosfat (12.61.0) gübresi }(3.6 \mathrm{~kg} \\
\text { saf } \mathrm{N} \text { ve } 18.3 \mathrm{~kg} / \mathrm{da} \text { saf } \mathrm{P}_{2} \mathrm{O}_{5} \text { ) düssecek şekilde çizilerin yanına uygulanmıştır. }\end{array}$ \\
\hline $\begin{array}{l}\text { Ara Çapa } \\
\text { Intermediate hoeing }\end{array}$ & Soya bitkileri 4. ve.6. yaprak arasında iken çapa makinası ile 2 kez çapa çekilmiştir. \\
\hline $\begin{array}{l}\text { Yabancı ot kontrolü } \\
\text { Weed control }\end{array}$ & $\begin{array}{l}\text { Bitki 4. ve } 6 \text {. yaprak gelişiminde el kazması ve ara çapa ile yabancı ot mücadelesi } \\
\text { yapılmıştır. }\end{array}$ \\
\hline $\begin{array}{l}\text { Zirai Mücadele } \\
\text { Agr. spraying }\end{array}$ & $\begin{array}{l}\text { Tarla pülverizatörü ile } 4 \text {. ve } 6 \text {. yaprakta yabancı ot ve zararlı mücadelesi } 2 \text { kez (ilaç } \\
\text { normuna göre) uygulanmıştır. }\end{array}$ \\
\hline $\begin{array}{l}\text { Sulama } \\
\text { Irrigation }\end{array}$ & $\begin{array}{l}\text { İlk sulama yağmurlama sulama ile daha sonraki sulamalar çevresel koşullara göre } \\
\text { 10-15 gün aralıklarla toplam } 4 \text { sulama yapılmıştır. }\end{array}$ \\
\hline
\end{tabular}

Hasat

Hasat işlemi 02 Ekim 2019'dabiçerdöverle yapılmıştır.

Harvest

Araştırmada elde edilen veriler JMP 5.0.1 istatistik paket programı kullanılarak, tesadüf bloklarında bölünmüş parseller deneme desenine göre istatistik analizine tabii tutulmuş, uygulamalar arasındaki farklılıklar varyans analizi yoluyla tespit edilmiştir. Elde edilen ortalama değerler arasındaki farklılıklar ise E.G.F Çoklu Karşılaştırma Testi kullanılarak \%5 düzeyinde karşılaştırılmıştır.

\section{ARAŞTIRMA BULGULARI ve TARTIŞMA}

\section{Fenolojik Gözlemler}

Araştırmada materyal olarak kullanılan iki farklı soya çeşitlerine ait belirlenen fenolojik gözlem sonuçları gün olarak tespit edilmiştir. Arısoy soya çeşidinin çıkış süresi 6 . gün, çiçeklenme için gereken süre 38. gün ve olum için gereken süre 138 gün olmuştur. Lider soya çeşidinde ise bu değerler sırası ile 7 . gün, 37 gün ve 140. gün olarak belirlenmiştir.

Kınacı, 2011, Çanakkale koşullarında yürüttükleri denemede, 10 çeşit ve 1 aday hat kullanmış ve bitkilerin çıkış süreleri 5-10 gün; çiçeklenme süreleri 57-65 gün ve olum süreleri 140-150 gün arasında tespit etmiştir. Altınyüzük, 2017, Adana'da ikinci ürün koşullarında 15 soya çeşidi ile yürüttüğü çalışmada, ilk çiçeklenme gün sayısının 24-38 gün, olum gün sayısın 103-110 gün arasında değiştiğini bildirmiştir. Araştırmada Arısoy ve Lider tohum çeşitlerinin fenolojik gözlem değerlerinin literatürle uyumlu olduğu görülmektedir.

\section{Yapılan Ölçüm ve Analiz Sonuçları}

Araştırmada kullanılan soya çeşitlerinden elde edilen bitki boyu, dal sayısı, hasat artığı miktarı, hasat indeksi, tohum verimi ve bakladaki biyomas ağırlı̆̆ı değerlerine ilişkin varyans analiz sonuçları, elde edilen ortalama değerler ile $\mathrm{EGF}(\% 5)$ 'e göre oluşan gruplar Çizelge 3'de verilmiştir.

\section{Bitki boyu}

Çizelge 3 incelendiğinde, Arısoy çeşidinde bitki boyu $115.35 \mathrm{~cm}$, Lider çeşidinde ise $88.03 \mathrm{~cm}$ olarak gerçekleşmiştir. Çeşit farkı gözetilmediğinde uygulanan iki farklı budamanın bitki boyunda bir düşüşe neden olduğu gözlenmiştir. Bu düşüş özellikle 5B uygulamasında daha belirgin olmuştur. Bitki boyu 0B uygulamasinda $107.81 \mathrm{~cm}, 3 \mathrm{~B}$ uygulamasinda $101.18 \mathrm{~cm}$ ve $5 \mathrm{~B}$ uygulamasinda $96.08 \mathrm{~cm}$ olarak gerçekleşmiştir. Yapılan istatistik analizde 3B ile 5B uygulamalarının 0B uygulamasına göre fark önemli çıkmıştır. Çeşit x Uygulama arasındaki interaksiyon durumu incelendiğinde, bitki boyu en yüksek Arısoy çeşidinin 0B uygulamasında $(121.93 \mathrm{~cm})$, en düşük değer ise Lider çeşidinin 5B uygulamasında $(82.25 \mathrm{~cm})$ gerçekleşmiştir. Her iki çeşit içinde kontrol grubu (0B) en yüksek bitki boyunu vermiş ve bunu sırasıyla $3 \mathrm{~B}$ ve 5B uygulamaları takip etmiştir. Tepe budama uygulamaları her iki çeşitte de bitki boyunu olumsuz etkilemiştir. Çiçeklenme gün sayısı, olgunlaşma gün sayısı ve bitki boyu; soyanın adaptasyonu ve verimliliğini etkileyen önemli özelliklerdir (Cober ve Morrison, 2010). Bakal ve ark., 2017, Adana koşullarında 12 soya çeşidi ile yürütmüş oldukları araştırmada, ana ürün koşullarında yetiştirdikleri tüm çeşitlerin bitki boyunu (103.3-135.8 cm), ikinci ürün koşullarındakinden (93.6-123.4 cm) daha yüksek tespit ettiklerini bildirmişlerdir. 
Çizelge 3. Araştırmada kullanılan soya çeşitlerinden elde edilen bitki boyu, dal sayısı, hasat indeksi, hasat artığı miktarı, tohum verimi ve biyomas ağırlığı değerlerine ilişkin varyans analiz sonuçları, elde edilen ortalama değerler ile $\mathrm{EGF}(\% 5)$ 'e göre oluşan gruplar

Table 3. Variance analysis results related to plant height, branch number, harvest index, harvest residue amount, seed yield and biomass weight values obtained from the soybean varieties used in the research, groups formed according to the mean values obtained and EGF (5\%)

\begin{tabular}{|c|c|c|c|c|c|c|c|}
\hline $\begin{array}{l}\text { Varyans Kaynağı } \\
\text { (Variance analysis) }\end{array}$ & & $\begin{array}{c}\text { Bitki Boyu } \\
(\mathrm{cm}) \\
(\text { Plant height) }\end{array}$ & $\begin{array}{c}\text { Dal Sayısı } \\
\text { (adet bitki-1) }^{-1} \\
\text { (Branch } \\
\text { number) }\end{array}$ & $\begin{array}{c}\text { Hasat } \\
\text { Artığ1 } \\
\left(\mathrm{kg} \mathrm{da}^{-1}\right) \\
\text { (Harvest } \\
\text { residue) }\end{array}$ & $\begin{array}{l}\text { Hasat } \\
\text { indeksi } \\
\text { (Harvest } \\
\text { index) }\end{array}$ & $\begin{array}{c}\text { Tohum } \\
\text { Verimi } \\
\left(\mathrm{kg} \mathrm{da}^{-1}\right) \\
(\text { Seed } \\
\text { yield) }\end{array}$ & $\begin{array}{c}\text { Biyomas } \\
\text { Ağırlığ } 1(\mathrm{~kg} \\
\left.\text { da }^{-1}\right) \\
(\text { Biomass } \\
\text { weight })\end{array}$ \\
\hline \multirow{2}{*}{$\begin{array}{l}\text { Çeşit } \\
\text { Variety }\end{array}$} & Arisoy (A) & $115.35 \mathrm{a}$ & $4.55 \mathrm{a}$ & 896.53 & 0.35 & $485.17 \mathrm{a}$ & $1381.7 \mathrm{a}$ \\
\hline & Lider (L) & $88.03 \mathrm{~b}$ & $3.37 \mathrm{~b}$ & 912.1 & 0.36 & $512.75 \mathrm{a}$ & $1424.9 \mathrm{a}$ \\
\hline $\mathrm{P}$ & & 0.0001 & 0.0004 & 0.6 & 0.1 & 0.1 & 0.3 \\
\hline EGF & & 4.85 & 0.55 & 60.6 & 0.02 & 30.57 & 78.14 \\
\hline \multirow[t]{2}{*}{ Uygulama } & $0 \mathrm{~B}$ & $107.81 \mathrm{a}$ & $2.42 \mathrm{~b}$ & 877.38 & $0.36 \mathrm{a}$ & $500.97 \mathrm{a}$ & $1378.4 \mathrm{ab}$ \\
\hline & $3 \mathrm{~B}$ & $101.18 \mathrm{~b}$ & $4.80 \mathrm{a}$ & 904.61 & $0.34 \mathrm{~b}$ & $459.60 \mathrm{~b}$ & $1364.2 \mathrm{~b}$ \\
\hline Treatment & $5 \mathrm{~B}$ & $96.08 \mathrm{~b}$ & $4.64 \mathrm{a}$ & 930.95 & $0.37 \mathrm{a}$ & $536.31 \mathrm{a}$ & $1467.3 \mathrm{a}$ \\
\hline $\mathrm{P}$ & & 0.0021 & 0.0001 & 0.3 & 0.006 & 0.0078 & 0.1 \\
\hline EGF & & 5.94 & 0.67 & 74.23 & 0.02 & 37.43 & 95.7 \\
\hline \multirow{3}{*}{ ÇeşitxUyg. } & $\mathrm{Ax} 0 \mathrm{~B}$ & $121.93 \mathrm{a}$ & $3.41 \mathrm{c}$ & 860.12 & $0.35 \mathrm{abc}$ & $461.31 \mathrm{c}$ & $1321.4 \mathrm{~b}$ \\
\hline & $\mathrm{Ax} 3 \mathrm{~B}$ & $114.21 \mathrm{ab}$ & $5.03 \mathrm{ab}$ & 883.04 & $0.33 \mathrm{c}$ & $440.63 \mathrm{c}$ & $1323.67 \mathrm{~b}$ \\
\hline & $\mathrm{Ax} 5 \mathrm{~B}$ & $109.92 \mathrm{~b}$ & $5.20 \mathrm{a}$ & 946.43 & $0.37 \mathrm{ab}$ & $553.57 \mathrm{a}$ & $1500.0 \mathrm{a}$ \\
\hline \multirow{3}{*}{ Variety $x$ Treatment } & Lx0B & $93.69 \mathrm{c}$ & $1.44 \mathrm{~d}$ & 894.64 & $0.38 \mathrm{a}$ & $540.63 \mathrm{a}$ & $1435.3 \mathrm{ab}$ \\
\hline & Lx3B & $88.17 \mathrm{~cd}$ & $4.58 \mathrm{ab}$ & 926.19 & $0.34 \mathrm{bc}$ & $478.57 \mathrm{bc}$ & $1404.8 \mathrm{ab}$ \\
\hline & Lx5B & $82.25 \mathrm{~d}$ & $4.08 \mathrm{bc}$ & 915.48 & $0.36 \mathrm{ab}$ & $519.05 \mathrm{ab}$ & $1434.5 \mathrm{ab}$ \\
\hline $\mathrm{P}$ & & 0.0001 & 0.0001 & 0.6 & 0.01 & 0.0077 & 0.1 \\
\hline EGF & & 8.4 & 0.95 & 104.97 & 0.03 & 52.94 & 135.34 \\
\hline CV (\%) & & 5 & 16 & 8 & 5 & 7 & 6 \\
\hline
\end{tabular}

\section{Dal Sayısı}

Bitki başına düşen dal sayısının Lider çeşidinde 3.37 adet, Arısoy çeşidinde ise 4.55 adet olduğu belirlenmiştir. Çeşit farkı gözetilmediğinde uygulamalar arasında bitki başına düşen dal sayısının 0B uygulamasinda 2.42 adet, $3 \mathrm{~B}$ uygulamasinda 4.80 adet ve 5B uygulamasinda 4.64 adet olarak gerçekleşmiştir. Diğer deyişle, $3 \mathrm{~B}$ ve $5 \mathrm{~B}$ uygulamalarında bitki başına düşen dal sayısının 0B uygulamasına göre daha yüksek olduğu gözlenmiştir (Çizelge 3). Bu durum, tepe sürgün budamasının dal sayısını önemli ölçüde arttırdığını göstermektedir. Yapılan istatistiksel analizde $3 \mathrm{~B}$ ile $5 \mathrm{~B}$ uygulamalarının OB uygulamasına göre fark önemli çıkmıştır. Soya hem vejetatif hem de generatif esnekliğe sahip bir bitkidir (Egli, 1993). Soyanın fenotipik esnekliğini gerçekleştirme kabiliyeti, indeterminant özelliği, dallanmadaki değişkenliği ve tohum üretme potansiyeli ile ilişkilidir (GreenTracewicz ve ark., 2011). Soyada dal sayısı önemli bir verim bileşenidir. Farklı çevrelerde ana sap verimi çok fazla değişim göstermemekte, verim düşüşlerinin sorumlusu ana saptan ziyade yan daldaki verim azalmaları olmaktadır (Board, 1985).

Çeşit $\mathrm{x}$ Uygulama arasındaki interaksiyon durumu incelendiğinde, bitki başına düşen dal sayısının en yüksek Arısoy çeşidinin 3B ve 5B uygulamalarında, Lider çeşidinde ise 3B uygulamasında gerçekleşmiştir (Çizelge 3). Lider çeşidinde çok düşük dal sayısının elde edilmesi bu çeşidin geleneksel yetiştirilme ortamında dallanmaya müsait olmadığını göstermektedir.

\section{Biyomas Ağırlığı}

Araştırmada incelenen soya çeşitlerinde dekara düşen biyomas ağırlığı Lider çeşidinde $1425 \mathrm{~kg}$, Arısoy çeşidinde ise $1382 \mathrm{~kg}$ olarak gerçekleşmiştir. Istatistiksel analizde iki çeşit arasındaki fark önemli çıkmamıştır.

Çeşit $\mathrm{x}$ Uygulama arasındaki interaksiyonda görüldüğü üzere, Arısoy çeşidinde dekara biyomas ağırlığı 0B uygulamasinda $1321.4 \quad \mathrm{~kg}, \quad 3 \mathrm{~B}$ uygulamasinda $1323.67 \mathrm{~kg}$ ve $5 \mathrm{~B}$ uygulamasinda $1500.00 \mathrm{~kg}$ olarak gerçekleşmiştir. Bu değer, Lider çeşidinde ise sırası ile 1435.3 / 1404.8 / $1434.5 \mathrm{~kg}$ olarak gerçekleşmiştir. Diğer deyişle, Arısoy çeşidinde dekara biyomas ağırlığ $0 \mathrm{~B}$ uygulamasına göre $3 \mathrm{~B}$ uygulamasinda $2.27 \mathrm{~kg}$, 5B uygulamasinda $178.6 \mathrm{~kg}$ fark bulunurken Lider çeşidinde bu değer sırası ile (30.5) $\mathrm{kg}$ ve (-0.8) kg olarak hesaplanmıştır (Çizelge 3). Araştırmada, Arısoy çeşidinde 5B uygulamasının biyomas ağırlığına önemli etkisi olduğu tespit 
edilmiştir. Lider çeşidinde ise budamanın biyomas ağırlığı artışına ters tepki göstermiştir. İstatistiksel analizde Lider çeşidinde uygulamalar arasında fark önemli çıkmazken Arısoyda 5B uygulamasının 0B ile 3B uygulamaları arasındaki fark önemli çıkmıştır.

Soya, tohumu yanında samanı ve biyokütlesi ile de ekonomik olarak değeri olan bir baklagil türüdür (Krisnawati ve Adie, 2015). Bir bitkisel tarım ürününün tohum verimi, üretilen toplam biyokütlenin ve bu biyokütlenin tohumlara sevkinin hasat indeksiyle derecelendirilen bir fonsksiyonudur (Pereira-Flores ve Justino, 2019). Aserse ve ark., 2019, iki yıl boyunca dört lokasyonda yürüttükleri çalışmada soyada biyomas miktarını en yüksek $718 \mathrm{~kg} \mathrm{da}^{-1}$ olarak tespit ettiğini bildirmişlerdir. Araştırmada, biyomas ağırlığının her iki çeşitte de elde edilen değerlerin literatür verilerinden daha yüksek çıtığ görülmektedir. Bunun nedeni ise, biyomas verimliliğini arttırmak için geleneksel üretimden daha yoğun gübreleme ve bakım işlemlerin yapılmasından kaynaklandığı düşünülmektedir.

\section{Hasat Artığı Miktarı}

Araştırmada incelenen soya çeşitlerinin dekara hasat artığı miktarının her iki çeşitte de benzer değerler almış olup, bu değer Lider ve Arısoy çeşitlerinde sırasıyla 912 ve $897 \mathrm{~kg}$ olarak gerçekleşmiştir (Çizelge 3). Hasat artığı miktarı değerleri uygulamalardan da etkilenmediği ve uygulamalar arasındaki farkın istatistiksel olarak önemli olmadığ Krisnawati ve Adie, 2015 tarafindan yapılan çalışmada, soyada dekara hasat artığı biyoküle miktarının $303.4 \quad-533.0 \mathrm{~kg}$ arasında değişim gösterdiğini bildirmişlerdir.

Çizelge 3 incelendiğinde Çeşit $\mathrm{x}$ Uygulama interaksiyonunda önemli bir fark görülmediği tespit edilmiştir. Soya, tohumu yanında samanı ve biyokütlesi ile de ekonomik olarak değeri olan bir baklagil türüdür (Krisnawati ve Adie, 2015). Araştırmada, biyomas miktarı çeşitlerden etkilenmemişken uygulamalardan etkilenmiş, hasat

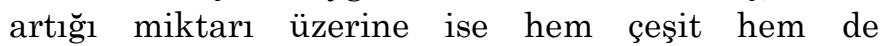
uygulamalar etkisiz olduğu gözlenmiştir. Bu durum, biyomas miktarındaki değişimin tamamıla dane miktarındaki artıştan etkilendiğini göstermektedir. Yani tepe budama uygulamaları incelenen çeşitlerde hasat artığı miktarına etki etmemiştir.

\section{Hasat İndeksi (HI)}

Araştırmada ele alınan soya çeşitlerinin arasındaki hasat indeksi değerlerinin birbirlerine göre benzer değişim göstermiş olup, bu değer Lider ve Arısoy çeşitlerinde sirasıyla \%36 ve \%35 olduğu belirlenmiştir. Çeşit farkı gözetilmediğinde uygulamalar karşılaştırıldığında hasat indeksi değerlerinde önemli değişimler saptanmıştır. Hasat indeksi en yüksek $\% 37$ ile $5 \mathrm{~B}$ uygulamasında görülürken bunu sırası ile 0B uygulaması (\%36) ve 3B uygulaması (\%34) izlemiştir (Çizelge 3). Yetgin, 2008, Çukurova Bölgesi ana ürün koşullarında bazı soya çeşit ve hatları kullandığı araştırmasında, en yüksek hasat indeksi değerini \%31.0 ile Atakişi, en düşük ise \%17.3 ile Nazlıcan çeşidinden elde ettiğini belirlemiştir.

Çizelge 3'deki interaksiyon durumu incelenmesinde görüleceği gibi, hasat indeksi en düşük değer her iki çeşidin 3B uygulamasında gerçekleşmiştir. Uygulamalara çeşitlerin reaksiyonları çok farklı olmuştur. Dallanmaya müsait olan Arısoy çeşidi, kontrole kiyasla 5B uygulamasina olumlu tepki göstermesine karşın 3B uygulamasına ise olumsuz tepki vermiştir. Diğer deyişle, Arısoy'da uygun budama zamanı bitkinin 5 yapraklı olduğu aşamada gözlenmiştir. Dallanma yeteneği düşük çeşit olan Lider'de ise HI en yüksek değeri OB uygulamasında, en düşük değeri ise 3B uygulamasında almıştır. Yani Lider çeşidi HI açısından budamaya ters tepki göstermiştir.

\section{Tohum Verimi}

Çizelge 3 incelendiğinde, denemeye alınan soya çeşitlerinin tohum verimi değerlerinin birbirinden farklı olmadiğ $\breve{l}_{1}$ tespit edilmiştir. Dekara tohum veriminin Lider çeşidinde $512.8 \mathrm{~kg}$, Arısoy çeşidinde ise $485.2 \mathrm{~kg}$ olarak gerçekleşmiştir. Çeşit farkı gözetilmediğinde tohum verimi $5 \mathrm{~B}$ uygulamasında en yüksek $(536.3 \mathrm{~kg}), 3 \mathrm{~B}$ uygulamasında ise en düşük değere $(459.6 \mathrm{~kg}) \quad$ ulaşmıştır. Tohum verimi $3 \mathrm{~B}$ uygulamasinda olumsuz, $5 \mathrm{~B}$ uygulamasinda ise olumlu etkilendiği tespit edilmiştir. $\mathrm{Bu}$ nedenle, yapılacak budama zamanı bitki mimarisinde uygulanacak budamada önemli bir parametre olduğunu göstermektedir. Arığlu ve ark., 2013, 16 çeşidi Çukurova koşullarında ikinci ürün koşullarında test ettikleri çalışmada en yüksek verimi $\left(367 \mathrm{~kg} \mathrm{da}^{-1}\right)$ Arısoy çeşidinin verdiğini, Doğan ve ark., 2015 ise, beş soya çeşidini test ettikleri çalışmada en yüksek tohum verimi veren çeşidin Blaze olduğunu bildirmişlerdir.

İnteraksiyon durumu incelenmesinden görüleceği gibi, tohum verimi en yüksek Arısoy çeşidinde 5B uygulamasında, Lider çeşidinde ise $0 \mathrm{~B}$ ve $5 \mathrm{~B}$ uygulamalarında gerçekleşmiştir. En önemli parametre olan tohum verimi açısından Lider çeşidinin budamaya ihtiyacının olmadığı, Arısoy çeşidinin ise 5B uygulamasında budamanın yapılması gerektiği tespit edilirken, 3B uygulamasının verime herhangi bir katkısının olmadığı belirlenmiştir. Uygulamalar arasındaki benzer değişimin hasat indeksinde de görülmesi, budamanın verimde oluşturduğu değişimin HI ile yakından bağlantılı olduğunu göstermektedir.

\section{SONUÇ ve ÖNERILLER}

İki farklı soya çeşidinde tepe sürgününün kesilerek 
bitki mimarisinde oluşturulacak değişimin biyomas verimini artırma potansiyelini belirlemek amacıyla yapılan bu çalışmada elde edilen sonuçlar ve öneriler aşağıda gibi sıralanabilir;

- Tepe sürgün budama uygulamaları her iki çeşitte de bitki boyunu düşürürken dal sayısını yükseltmiştir.

- Arısoy çeşidinde budamaya tepki olarak biyomas miktarında artış, Lider çeşidinde ise fark görülmemiştir. Arısoy çeşidinde bitki boyunda görülen düşüşe karşın dal sayısı ve biyomas miktarında artış meydana gelmiştir.

- Tepe sürgünü alma uygulaması 3B uygulamasında hasat indeksi değerini en düşük değere düşürmüştür.

- Tepe sürgün budama uygulaması kontrol grubuna kiyasla 5B uygulamasinda tohum verimini artırırken, 3B uygulamasında ise düşürmüştür. Bitki mimarisinin olumlu etkilemesi için budama zamanın iyi ayarlanması gerektiği tespit edilmiştir.

- Tohum verimi en yüksek Arısoy çeşidinin 5B uygulamasında görünürken, Lider çeşidinin iki farklı uygulamasında (3B ve $5 \mathrm{~B}$ ) ters tepki vermiştir. $\mathrm{Bu}$ durum Lider çeşidinin budamaya ihtiyaç olmadığını, Arısoy çeşidinin ise budamayla veriminin artırılabileceği gözlenmiştir. Arısoy çeşidinde yapılacak budamanın beş yaprak aşamasının uygun olduğu belirlenmiştir.

- 3B uygulamasinda tohum veriminin düşmesinden dolayı yapılacak budama mimarisinin olumlu etkilenmesi için budama zamanının seçilmesinde dikkatli olunması gerektiği belirlenmiştir.

\section{Teşekkür}

$\mathrm{Bu}$ çalışmada materyallerin analizi ve deneysel sonuçları Çukurova Üniversitesi, Bilimsel Araştırma Projeleri Yönetim Birimi (Proje No: FBA-2019-11388) tarafından desteklenen projeden alınmıştır. Destekleri için teşekkür ediyoruz.

\section{Çıkar Çatışması Beyanı}

Makale yazarları aralarında herhangi bir çıkar çatışması olmadığını beyan ederler.

\section{Araştırmacıların Katkı Oranı Beyan Özeti}

Yazarlar makaleye eşit oranda katkı sağlamış olduklarını beyan ederler.

\section{KAYNAKLAR}

Ali A, Fletcher R A 1970. Hormonal Regulation of Apical Dominance in Soybeans. Canadian Journal of Botany 48(11): 1989-1994.

Altınyüzük H 2017. Soya Çeşitlerinin Çukurova Koşullarında II. Ürün Olarak Verim ve Kalite Özelliklerinin İncelenmesi. Selçuk Üniversitesi Fen Bilimleri Enstitüsü, Yüksek Lisans Tezi, 75sy.

Arıoğlu H, Özyurtseven S, Onat B, Güllüoğlu L 2013. İkinci Ürün Koşullarında Bazı Soya [Glycine max
(L.) Merr] Çeşitlerinin Önemli Bitkisel Özelliklerinin Belirlenmesi. I. Türkiye 10. Tarla Bitkileri Kongresi Bildiri Kitapçı̆̆ı, Cilt II:409-414, Konya.

Aserse A A, Markos D, Getachew G, Yli-Halla M, Lindström K 2019. Rhizobial Inoculation Improves Drought Tolerance, Biomass and Grain Yields of Common Bean (Phaseolus vulgaris L.) and Soybean (Glycine max L.) at Halaba and Boricha in Southern Ethiopia. Archives of Agronomy and Soil Science: 114. https://doi.org/10.1080/03650340.2019.1624724.

Bakal H, Güllüoglu L, Onat B, Arığlu H 2017. The Effect of Growing Seasons on Some Agronomic and Quality Characteristics of Soybean Varieties in Mediterranean Region in Turkey. Turkish Journal Of Field Crops 22(2): 187-196.

Board J E 1985. Yield Components Associated with Soybean Yield Reductions at Nonoptimal Planting Dates. Agronomy journal 77(1): 135-140.

Brun W A, Betts K J 1984. Source/Sink Relations of Abscising and Nonabscising Soybean Flowers. Plant Physiol 75: 187-191.

Cober E R, Morrison M J 2010. Regulation of Seed Yield and Agronomic Characters by Photoperiod Sensitivity and Growth Habit Genes in Soybean. Theoretical and applied genetics 120(5):1005-1012.

Dybing C D, Reese Z N 2008. Nitrogen and Carbohydrate Nutrient Concentrations and Flower Set in Soybean Glycine Max (L.) merr. Journal Biol Sci 8(1): 24-33.

Doğan Y, Koyutürk Ö, Aktaş H 2015. Mardin-Kızıltepe Ekolojik Koşullarında Ekim Zamanı Uygulamalarının Bazı Soya Fasulyesi (Glycine max L.) Ceşitlerinde Verim ve Verim Öğeleri Üzerine Etkisi. Yüzüncü Yıl Üniversitesi Tarım Bilimleri Dergisi 25(3): 293-303.

Egli D B 1993. Cultivar Maturity and Potential Yield of Soybean. Field Crops Research 32(1-2): 147-158.

Green-Tracewicz E, Page E R, Swanton C J 2011. Shade Avoidance in Soybean Reduces Branching and İncreases Plant-to-Plant Variability in Biomass and Yield per Plant. Weed Science 59(1): 43-49.

Faostat 2018. http://www.fao.org/faostat/en/\#data/QC

Frederick J R, Camp C R, Bauer P J 2001. DroughtStress Effects on Branch and Mainstem Seed Yield and Yield Components of Determinate Soybean. Crop Science 41(3): 759-763.

Islam M O, Rahim M A, Prodhan A K M A 2010. Flowering Pattern, Floral Abscission and Yield Attributes in Soybean Influenced by GABA. Journal of the Bangladesh Agricultural University 8(1): 2933.

Kınacı M 2011. Çanakkale Koşullarında Soya Fasulyesi Çeşitlerinin Verim ve Bazı Kalite Unsurlarının Belirlenmesi. Selçuk Üniversitesi Fen Bilimleri Enstitüsü Yüksek Lisans Tezi, 69sy.

Kokubun M 2011. Physiological Mechanisms Regulating Flower Abortion in Soybean. INTECH 
Open Access Publisher.

Kokubun M, Honda I 2000. Intra-Raceme Variation in Pod-Set Probability is Associated with Cytokinin Content in Soybeans. Plant Production Science 3(4): 354-359.

Krisnawati A, Adie M M 2015. Variability of Biomass and Harvest Index from Several Soybean Genotypes as Renewable Energy Source. Energy Procedia 65: 14-21.

Linkemer G, Board J E, Musgrave M E 1998. Waterlogging Effects on Growth and Yield Components in Late-Planted Soybean. Crop Science 38(6): 1576-1584.

Nonokawa K, Kokubun M, Nakajima T, Nakamura T, Yoshida R 2007. Roles of Auxin and Cytokinin in Soybean Pod Setting, Plant Production Science 10(2): 199-206.

Norsworthy J K, Shipe E R 2005. Effect of Row Spacing and Soybean Genotype on Mainstem and Branch
Yield. Agronomy Journal 97(3): 919-923.

Pereira-Flores M E, Justino F B 2019. Yield Components and Biomass Partition in Soybean: Climate Change Vision. In Soybean-Biomass, Yield and Productivity. IntechOpen.

Robinson A P, Simpson D M, Johnson W G 2013. Response of Glyphosate-Tolerant Soybean Yield Components to Dicamba Exposure. Weed Science 61(4): 526-536.

Ruan Y L, Patrick J W, Bouzayen M, Osorio S, Fernie A R 2012. Molecular Regulation of Seed and Fruit Set. Trends in Plant Science 17(11): 656-665.

TÜİK 2018. https://biruni.tuik.gov.tr/bitkiselapp/ bitkisel.zul

Yetgin S 2008. Çukurova Bölgesinde Ana Ürün Koşullarında Bazı Soya Çeşit ve Hatlarının Verim ve Tarımsal Özelliklerinin Belirlenmesi. Çukurova Üniversitesi Fen Bilimleri Enstitüsü, Tarla Bitkileri Anabilim Dalı, Yüksek Lisans Tezi, 40sy. 